\title{
VARIATION IN RATES OF KARST PROCESSES
}

\section{SPREMENLJIVOST HITROSTI KRAŠKIH PROCESOV}

\author{
Arthur N. PALMER ${ }^{1}$
}

\begin{abstract}
UDC 551.44

Arthur N. Palmer: Variation in rates of Karst processes

The development of karst is not a linear process but instead takes place at irregular rates that typically include episodes of stagnation and even retrograde processes in which the evolution toward maturity is reversed. The magnitude and nature of these irregularities differs with the length of time considered. Contemporary measurements in caves show fluctuations in dissolution rate with changes in season, discharge, and soil conditions. Dissolution is sometimes interrupted by intervals of mineral deposition. Observed dissolution rates can be extrapolated to obtain estimates of long-term growth of a solution feature. But this approach is flawed, because as the time scale increases, the rates are disrupted by climate changes, and by variations that are inherent within the evolutionary history of the karst feature (e.g., increased $\mathrm{CO}_{2}$ loss from caves as entrances develop). At time scales of $10^{5}-10^{6}$ years, karst evolution can be interrupted or accelerated by widespread fluctuations in base level and surface river patterns. An example is the relation between karst and the development of the Ohio River valley in east-central U.S.A. At a scale of $10^{6}-10^{8}$ years, tectonic and stratigraphic events cause long-term changes in the mechanism and style of karst development. For example, much of the karst in the Rocky Mountains of North America has experienced two phases of pre-burial Carboniferous karst, mineral accretion during deep burial from Permian to Cretaceous, extensive cave development during Paleocene-Eocene uplift, and stagnation and partial mineral deposition caused by late Tertiary aggradation. At such large time scales, it is difficult to determine rates of karst development precisely, if at all. Instead it is appropriate to divide the evolutionary history into discrete episodes that correlate with regional tectonic and stratigraphic events.
\end{abstract}

Key words: Karst evolution, dissolution rates, retrograde processes, paleokarst.

\section{Izvleček}

UDK 551.44

Arthur N. Palmer: Spremenljivost hitrosti kraških procesov

Razvoj krasa ni lineareni proces, pač pa poteka s spremenljivo hitrostjo, značilna so tudi obdobja stagnacije in obdobja, ko je razvoj obrnjen v smeri manj zrele faze. Velikost in narava sprememb sta odvisni tudi od časovnega merila $v$ katerem jih opazujemo. Današnja merjenja $\mathrm{v}$ jamah kažejo, da je hitrost raztapljanja odvisna od letnega časa, pretoka in pogojev $\mathrm{v}$ prsti. Raztapljanje je občasno prekinjeno z obdobjem izločanja. Izmerjene hitrosti raztapljanja lahko ekstrapoliramo v času in na osnovi tega sklepamo o rasti določene korozijske oblike. Vendar bomo pri tem storili napako, saj merjenja ne vsebujejo dolgočasovnih sprememb. Te so lahko posledica različnih dejavnikov, kot so klimatske spremembe in spremembe, ki nastanejo zaradi samega razvoja krasa (npr. uhajanje $\mathrm{CO}_{2}$ zaradi odpiranja jamskih vhodov). V časovnem merilu $10^{5}-10^{6}$ let razvoj krasa prekinjajo ali pospešujejo spremembe erozijske baze in spremembe površinskih vodotokov. Tak primer je povezava med razvojem krasa in doline reke Ohio v vzhodnem delu centralnih ZDA. V časovnem merilu $10^{6}-10^{8}$ let tektonski in stratigrafski dogodki povzročajo dolgočasovne spremembe v razvoju krasu. Tak primer je kras v Skalnem gorovju v Severni Ameriki. Dvem fazam zakrasevanja $\mathrm{v}$ karbonu je sledil pokop in mineralna zapolnitev med permom in kredo. Temu je sledil obširen razvoj jam med paleocensko-eocenskim dvigom ter stagnacija in delna mineralna zapolnitev $\mathrm{v}$ poznoterciarni agradaciji. $\mathrm{V}$ tako velikem časovnem merilu je težko določiti hitrost razvoja krasa, če sploh. Primerneje je, da razvojno zgodovino razdelimo v obdobja, ki ustrezajo pomembnejšim regionalnim tektonskim in stratigrafskim dogajanjem.

Ključne besede: razvoj krasa, hitrost raztapljanja, procesi nazadovanja, paleokras.

\footnotetext{
${ }^{1}$ Department of Earth Sciences, State University of New York, Oneonta, NY 13820-4015, U.S.A.

e-mail: palmeran@oneonta.edu
}

Received/Prejeto: 27.11.2006 


\section{INTRODUCTION}

In any discussion of the age of karst, one must consider the rates of the genetic processes and how they vary with time. These are influenced by the length of time over which they have operated. Karst development undergoes large variations in rate and is commonly interrupted by periods of stagnation or even retrograde processes in which mass is accumulated instead of removed. This paper focuses on several field examples that illustrate these processes and the difficulty of quantifying them. These studies are still in progress and are used here only as points for discussion.

\section{SHORT-TERM VARIATIONS IN DISSOLUTION RATE}

One approach to interpreting karst history is to measure current rates of bedrock dissolution, for example by applying the mass balance, or by measuring rates of bedrock retreat with micrometers or standardized bedrock tablets. In the two following studies, empirical kinetic equations are applied. On the basis of prior dissolution experiments, field measurements of water chemistry are used to estimate dissolution or accretion rates at specific locations and times.

\section{Field example: eastern New York State}

Chemical measurements were made during 1985-1996 in streams of McFail's Cave, New York (Fig. 1; Palmer, 1996). Suitable data-loggers were not available for use in this flood-prone cave, so measurements were made randomly at every opportunity. Although statistically shaky

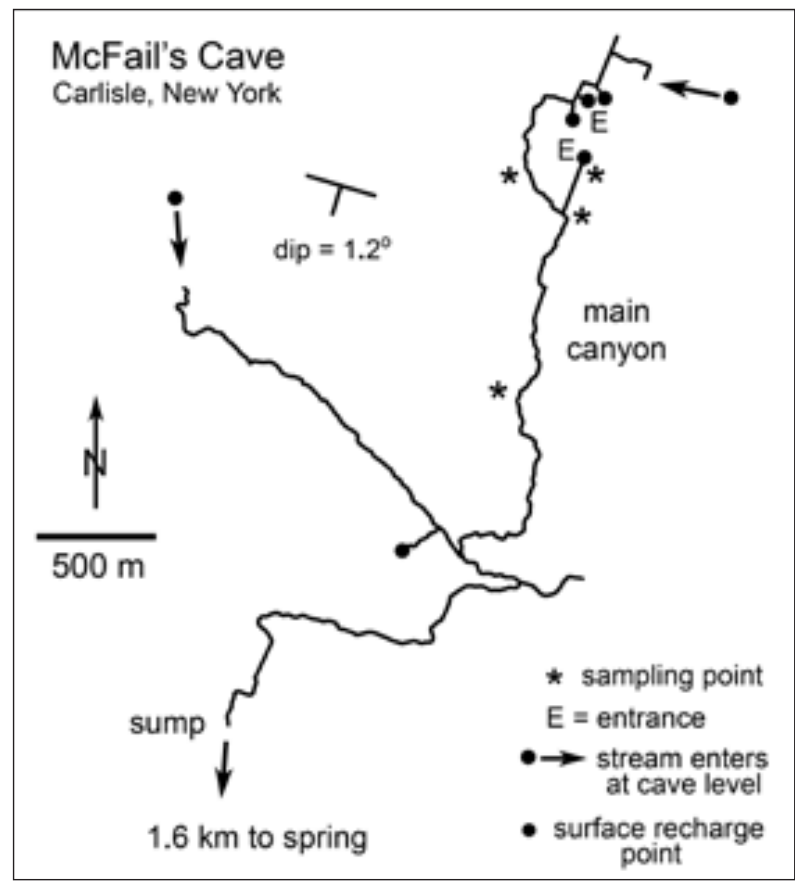

Fig. 1: Map of McFail's Cave, New York, showing location of sampling sites. compared to continuous or short-interval sampling, this approach allowed full chemical analyses.

The cave, in Silurian-Devonian limestones, consists of stream passages fed by dolines and ponors. Local soil $\mathrm{P}_{\mathrm{CO} 2}$ is $0.02-0.04$ atm, but in this well-aerated cave the mean $\mathrm{P}_{\mathrm{CO} 2}$ of streams is only $\sim 0.003$ atm. Most measurements were made in the main passage and were correlated with discharge, but this location was not accessible during high flow. To provide broader coverage, additional measurements were made in similar passages with year-round accessibility. Chemical variations between sampling sites were negligible compared to variations with time. To allow extrapolation, the measurements were combined in a probability plot (Fig. 2), in which SI $=\log (\mathrm{IAP} / \mathrm{K}), \mathrm{IAP}=$ $\left(\mathrm{Ca}^{2+}\right)\left(\mathrm{CO}_{32-}\right)$, and $\mathrm{K}=$ calcite solubility product.

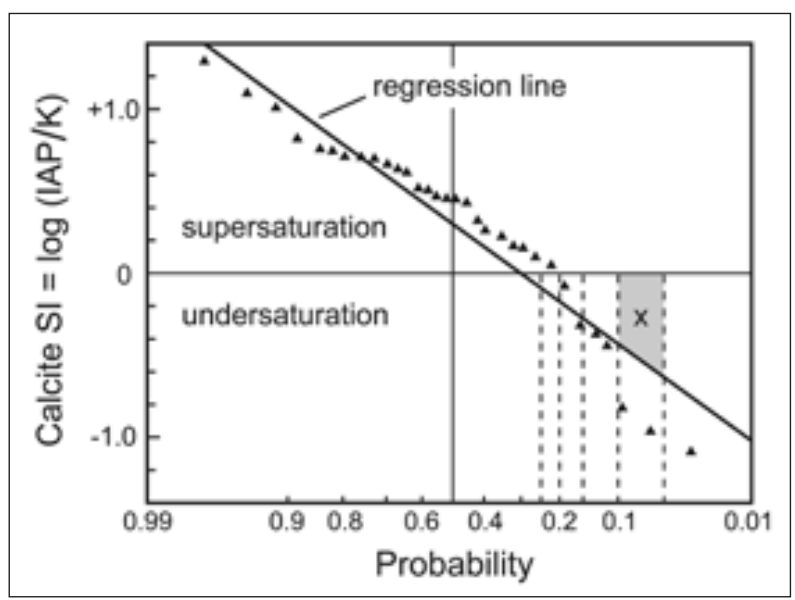

Fig. 2: Probability plot of calcite saturation index in McFail's Cave for the period 1985-1996, where $S I=\log (I A P / K)$. Data points are triangles; $X=$ example of probability interval used in Table 1.

Although the passages involved are active canyons, the water is conspicuously supersaturated except during the highest $20-30 \%$ of flow. At low flow the calcite SI often exceeds $+0.4(\sim 138 \%$ saturation $)$. Calcite can precipitate 
at approximately $\mathrm{SI}>+0.2$, so why does it not precipitate in the cave at those times?

During a particularly dry summer (1995), a conspicuous calcite layer did accumulate on the canyon floors. This coating averaged $0.3 \mathrm{~mm}$ thick with inclusions of clay and quartz silt (Figs. $3 \& 4$ ). It was limited to surfaces that remained water-covered during lowest flow and formed a continuous layer in areas of steep gradient (supercritical flow) but only discontinuous patches in ponded water.

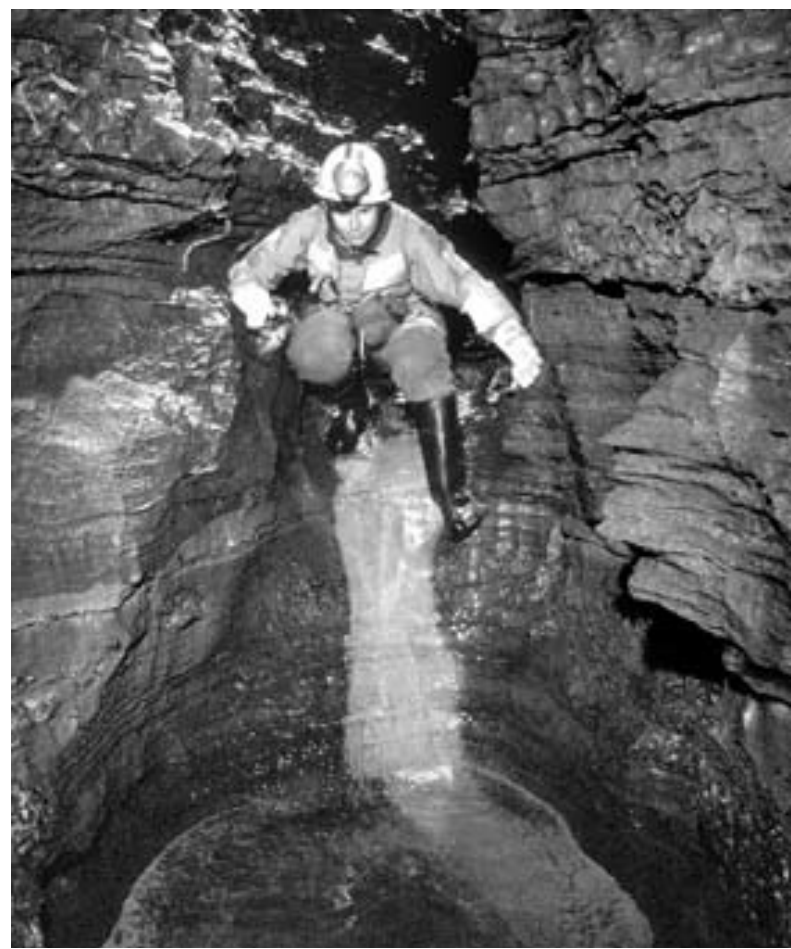

Fig. 3: Main stream of McFail's Cave during the summer of 1995, with calcite coating on floor of canyon.

In mid-January, 1996, heavy rain fell on rapidly melting snow and produced a flood with a return period of $\sim 50$ years. The main cave entrance was covered by $5 \mathrm{~m}$ of water, and smaller inputs contained roaring waterfalls. The calcite SI of the water entering the cave averaged 1.9 (cf. Fig. 2). This sample is not included in the statistics, as it was not random, but obtained purposely at the flood peak, and it is not in the same class as the in-cave samples. However, it illustrates the high dissolutional capacity of extreme floodwater.

The rate of limestone removal can be estimated by

$$
S=31.56 k\left(1-C / C_{s}\right)_{\mathrm{n}} / \rho \mathrm{cm} / \mathrm{yr}
$$

(Palmer, 1991), where $S=$ rate of bedrock retreat, $k=$ rate constant $(\mathrm{mg}-\mathrm{cm} / \mathrm{L}-\mathrm{sec}), n=$ reaction order $(\mathrm{di}-$ mensionless), $C_{s}=$ calcite saturation concentration, $C=$ actual concentration of dissolved calcite, and $\rho=$ rock density $\left(\mathrm{g} / \mathrm{cm}^{3}\right) . \mathrm{C} / C_{\mathrm{s}}$ is the saturation ratio, where 1.0 represents calcite saturation. From computer analysis, $C / C_{\mathrm{s}} \sim(\mathrm{IAP} / \mathrm{K})^{0.35}$. For the cave conditions (mean $\mathrm{P}_{\mathrm{CO} 2}$ $=0.003$ atm and $\mathrm{T}=8^{\circ} \mathrm{C}$ ), laboratory measurements by Plummer et al. (1978) show that $k \sim 0.01$ and $n \sim 2.2$ at $C / C_{\mathrm{s}}<0.6$, and $k \sim 0.05$ and $n \sim 4$ at $C / C_{\mathrm{s}}>0.6$ in opensystem turbulent flow. Bedrock density is $\sim 2.7 \mathrm{~g} / \mathrm{cm}^{3}$ in this low-porosity rock.

From chemical measurements during the winter and spring of 1996, it was predicted that the entire calcite coating of 1995 should have been removed by the time the cave became accessible in May. In fact, all but a few sheltered remnants of the calcite had been removed by then. Although mechanical abrasion may have aided the removal in places, the agreement between prediction and result is mild support for the validity of this approach.

Fig. 2 includes a best-fit regression line through the chemical data. Where this line extends below saturation, the probability scale was divided into $5 \%$ increments. From the mean SI in each increment, a net dissolution rate of $1.3 \times 10^{-3} \mathrm{~cm} / \mathrm{yr}$ was calculated for the period of study (Table 1). At that rate, the main cave stream would have deepened about $18 \mathrm{~cm}$ since the last glacial retreat in the region about 14,000 years ago. This is compatible with the presence of varved clays no more than a few centimeters above the lowest bedrock floors. The clay was deposited when retreating glaciers blocked the local surface river, flooding the valley and neighboring caves.

\begin{tabular}{|c|c|c|c|}
\hline $\begin{array}{c}\text { Probability } \\
\text { range }\end{array}$ & $\begin{array}{c}\text { Mean } \\
\mathrm{C} / \mathrm{C}_{s}\end{array}$ & $\begin{array}{c}\text { Mean S } \\
(\mathrm{cm} / \mathrm{yr})\end{array}$ & $\begin{array}{c}\text { Net annual } \\
\text { entrenchment }(\mathrm{cm})\end{array}$ \\
\hline$<0.05$ & $\sim 0.52$ & $\sim 0.017$ & $\sim 8.5 \times 10^{-4}$ \\
\hline $0.05-0.10$ & 0.65 & 0.0064 & $3.2 \times 10^{-4}$ \\
\hline $0.10-0.15$ & 0.74 & 0.0019 & $9.5 \times 10^{-5}$ \\
\hline $0.15-0.20$ & 0.88 & $8.8 \times 10^{-5}$ & $4.4 \times 10^{-6}$ \\
\hline $0.20-0.25$ & 0.89 & $7.4 \times 10^{-5}$ & $3.7 \times 10^{-6}$ \\
\hline $0.25-0.30$ & 0.95 & $2.1 \times 10^{-6}$ & $1.1 \times 10^{-7}$ \\
\hline & & TOTAL: $^{-6}$ & $\begin{array}{c}\mathbf{1 . 3} \times \mathbf{1 0} \mathbf{~ c m} / \mathbf{y r} \\
\mathbf{1 3} \mathbf{~ m m} / \mathbf{1 0 0 0} \mathbf{~ y r s}\end{array}$ \\
\hline
\end{tabular}

Tab. 1: Net dissolution rate in McFail's Cave canyons, 19851996, where the best-fit line in Fig. 2 falls below $S I=0$. Entrenchment rates are calculated from the regression line, rather than from specific data points, and provide only a rough approximation.

At the estimated entrenchment rate, the $10 \mathrm{~m}$ depth of the main McFail's canyon would have required more than 700,000 years to form. This rate seems low for an active canyon with a gradient of 1.2 degrees, but it is 


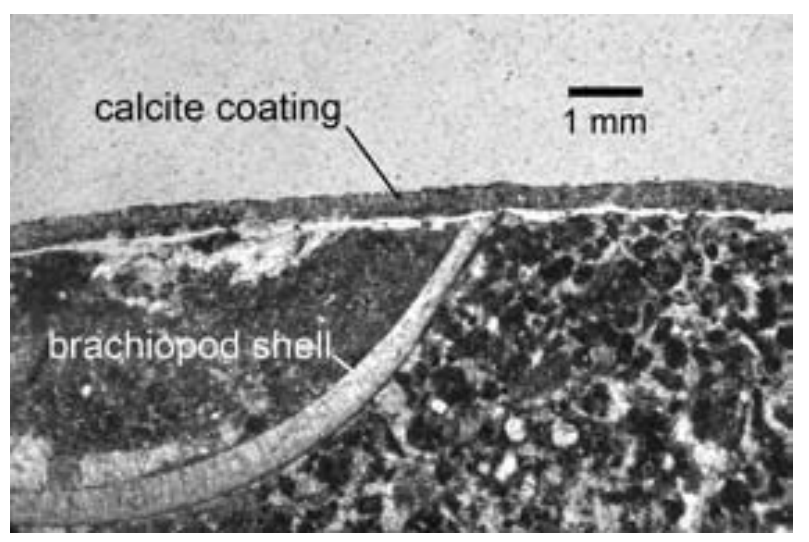

Fig. 4: Thin-section photomicrograph showing calcite crust on a limestone pebble from McFail's Cave (September, 1995).

compatible with U/Th speleothem dates. Related caves at the same elevation as McFail's contain speleothems dated up to $277 \mathrm{ka}$ (Dumont, 1995; Lauritzen \& Mylroie, 2000; Mylroie \& Mylroie, 2004). Some speleothems were located near the cave floors, so the passages themselves are far older. But the entrenchment rate during this period must have varied because of climate changes and burial beneath glacial ice for several tens of thousands of years. (The only known glaciation in the area was Wisconsinan.) The coarse bedload in parts of the cave also suggests mechanical abrasion during high flow.

The entrenchment rate has probably decreased with time. When entrances were blocked by glacial sediment, or had not yet enlarged enough to form open holes, escape of $\mathrm{CO}_{2}$ to the surface must have been severely lim- ited and the mean aggressiveness would have been higher than it is today. Also, calcareous glacial deposits cause low-flow inputs to be saturated with calcite before they even reach the cave.

The main canyon of the cave has an entirely vadose origin because it extends exactly down the local dip of the strata, except where it is deflected by joints (Fig. 1). Therefore the canyon originated after surface rivers had entrenched below its level (currently about $300 \mathrm{~m}$ above sea level). Although the age of the landscape is difficult to determine from the surface, data from the cave can provide helpful information.

\section{Mammoth Cave, Kentucky}

Meiman \& Groves (1997), Anthony \& Groves (1997), and Groves \& Meiman (2005) conducted a similar study in the main river passage of Mammoth Cave, Kentucky. They made a high-frequency record of water levels in monitor wells, combined with periodic measurements of water chemistry. To calculate dissolution rates, they used the kinetic equation described above. Because of thick sediment, cave enlargement rates could not be estimated precisely. However, the authors determined that during the highest $5 \%$ of flow, $38 \%$ of the mass was removed (vs. about $65 \%$ in McFail's). The difference is probably due, at least partly, to the lack of entrances near the sampling sites in Mammoth Cave through which $\mathrm{CO}_{2}$ is lost, the higher carbonate content of soils in the New York karst, and the dominance of sinking-stream inputs to McFail's Cave during severe floods.

\section{VARIATION IN KARST PROCESSES AT TIME SCALES OF $10^{5}-10^{6}$ YEARS}

The low-relief karst plateaus of Kentucky and Indiana, U.S.A., are developed on early Carboniferous carbonates and include extensive doline fields bordered by sinking streams. These include the Pennyroyal Plateau in Kentucky and the Mitchell Plain in Indiana. They are dissected to a maximum of $50-65 \mathrm{~m}$ by river valleys. Near rivers, inter-doline divides and residual flat areas lie 175-190 $\mathrm{m}$ above sea level, and up to a few tens of meters higher elsewhere. Although resistant beds form local flat areas, the overall surface is discordant to the strata. The surface is mantled in many places by residual, colluvial, and alluvial sediment up to $30 \mathrm{~m}$ thick, the surface of which is concordant with the erosion surface on nearby bedrock. In the Mitchell Plain the deposits are attributed to a widespread Tertiary rise in base level (Palmer \& Palmer, 1975). On the Pennyroyal, Ray (1996) calls this relatively flat surface the Green River Strath and attributes it to fluvial processes.
Caves are common in the karst plains and in adjacent sandstone-capped uplands. Mammoth Cave, Kentucky, is the best-known upland example. Its highest passages correlate with nearby low-relief areas of the Pennyroyal (Fig. 5), and passage patterns and gradients show that the Pennyroyal was the source of the cave water (Palmer, 1981). These passages are mostly large canyons filled partly or completely with stream sediment (Fig. 6). Dating of these sediments by cosmogenic radionuclides gives ages up to $4 \mathrm{Ma}$ (Granger et al., 2001), but in areas bordering the Green River (the outlet for Mammoth Cave water), most samples date to $\sim 2.2 \mathrm{Ma}$ (see also Anthony \& Granger, 2004, 2006). These passages record a history of slow Tertiary entrenchment interspersed with aggradation, and with a widespread rise in base level of more than $20 \mathrm{~m}$ at $\sim 2.2 \mathrm{Ma}$. The fragmentary sediment surfaces at the same elevation in the Pennyroyal must be correlative. The cause of the widespread aggradation at 


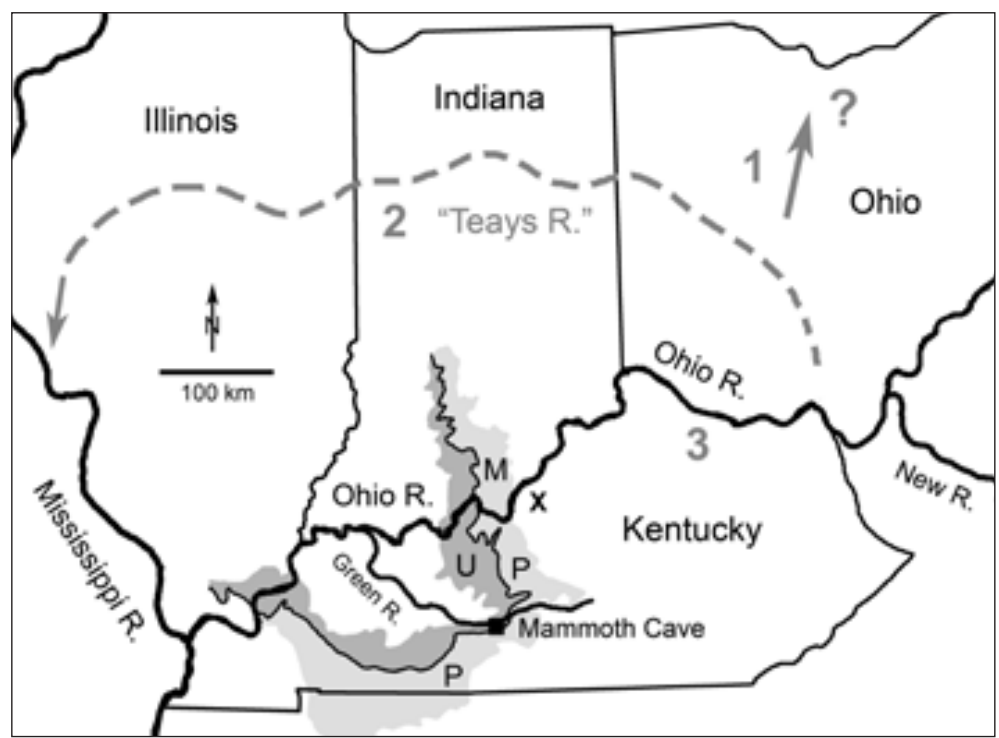

Fig.5: Location of Mammoth Cave and surrounding landscapes. $M=$ Mitchell Plain, $P=$ Pennyroyal Plateau, $U=$ sandstone-capped uplands. $X=$ pre-Pleistocene head of Ohio River. 1, 2, 3 = sequence of drainage from Appalachian Mountains. 1 is probable but entirely hypothetical. 2 = late Tertiary "Teays River," which is well known by its former valley, now filled with glacial sediment. $3=$ course of the Ohio River since the early Pleistocene. After Palmer (1981); see also Granger et al., (2001) for explanation.

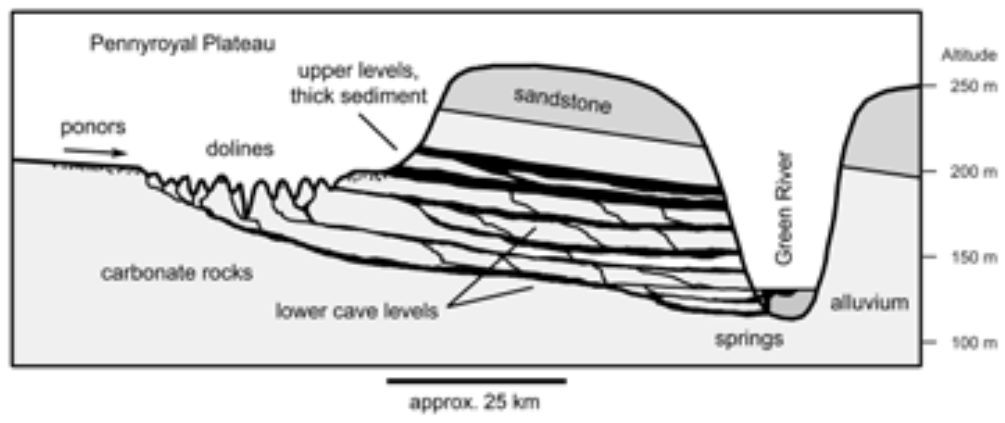

Fig. 6: Simplified cross section through the Pennyroyal Plateau and Mammoth Cave, Kentucky (after Palmer, 1981).

2.2 Ma is uncertain. It correlates roughly with the onset of widespread continental glaciation at higher latitudes, but it may relate more directly to a drying climate during the late Pliocene, which would have favored the accumulation of sediments in lowlands.

Pleistocene continental glaciers extended southward as far as northern Kentucky and caused much rearrangement of surface drainage. Initial entrenchment below the uppermost passages in Mammoth Cave may have been triggered by the establishment of drainage from the Appalachian Mountains westward to the Mississippi River, to form the so-called "Teays River" (Fig. 7; see Granger et al., 2001). Later, the previously tiny Ohio River became one of the largest rivers on the continent when the Teays was diverted into it (Fig. 7). These shifts en-

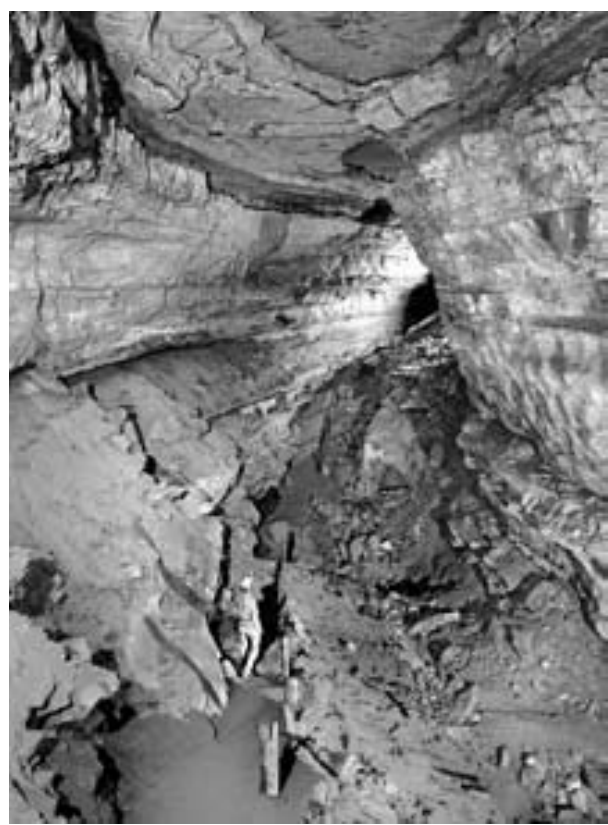

Fig. 7: Typical upper-level passage in Mammoth Cave with detrital sediment fill. This is a former tourist trail that is no longer open to the public. Sediment once filled the passage almost half-way but later subsided into an underlying passage. Note banks of remaining sediment on the left.

hanced the rate of river entrenchment into the sediment-mantled plains of carbonate rock. Subsurface karst drainage developed and the surfaces became "sinkhole plains." Pleistocene cave passages formed at various levels as much as $60-70 \mathrm{~m}$ below the Tertiary passages. Again, caves provide clues to the interpretation of surface landscapes that cannot be discerned from surface observations alone.

Could the karst plateaus have retained vestiges of their original flat surface for $2 \mathrm{Ma}$ without significant lowering? Although dolines extend deeply into them, nearly flat remnants of the sediment-covered and resistant bedrock surfaces remain at approximately the same elevations as the sediment in the upper-level passages of Mammoth Cave, which suggests that parts of the original surface have survived with little or no lowering.

What is the current karst denudation rate? Much of the Mammoth Cave area is drained by the Turnhole Spring basin, which has an area of $220 \mathrm{~km}^{2}$ (Quinlan et al., 1983). In this basin, Hess (1974) measured a meanannual Ca content of $\sim 60 \mathrm{mg} / \mathrm{L}$ and $\mathrm{Mg}$ of $\sim 7.5 \mathrm{mg} / \mathrm{L}$ (see also Hess \& White, 1993). These measurements represent a mean dissolved load of $\sim 0.044 \mathrm{~cm}^{3} / \mathrm{L}$ calcite and $\sim 0.020$ $\mathrm{cm}^{3} / \mathrm{L}$ dolomite (with the simplifying assumption that 
dolomite $=\mathrm{Mg}$ and calcite $=\mathrm{Ca}-\mathrm{Mg}$, in moles $/ \mathrm{L})$. The annual precipitation is $1.26 \mathrm{~m} / \mathrm{yr}$, and about $2 / 3$ of it lost to evapotranspiration, so a $220 \mathrm{~km}^{2}$ basin would have a mean runoff of roughly $9 \times 10^{7} \mathrm{~m}^{3} / \mathrm{yr}$. The loss of carbonate rock is therefore about $6000 \mathrm{~m}^{3} / \mathrm{yr}$. Roughly half of the basin consists of exposed carbonates, so the denudation rate on that half is about $5.5 \mathrm{~cm} / 1000$ years. This figure corresponds to some of the lowest measured rates of carbonate denudation elsewhere (Ford \& Williams, 1989, p. 112-117). Transport of solids is neglected, as is subsurface dissolution. The Mammoth Cave System represents a maximum porosity of about than $4 \%$, even in areas of maximum passage density (Palmer, 1995).

When the denudation rate is extrapolated to 2 million years, it indicates an overall lowering of the solu- ble Pennyroyal surface of roughly $100 \mathrm{~m}$. This is impossible, because it exceeds the total relief between the original surface and the Green River. There is no doubt that most of the surface has been lowered (Fig. 6), but there were evidently long periods of stagnation, especially at the beginning, when large parts of the surface were mantled with thick sediment. Most of the denudation is in the form of doline growth. Gams (1965) points out that corrosion accelerates in dolines as they grow, because of enhanced $\mathrm{CO}_{2}$ production in their thickening soils. Apparently the rate of karst denudation is higher today than during the early Pleistocene.

\section{KARST DEVELOPMENT AT TIME SCALES OF $10^{7}-10^{8}$ YEARS}

Karst that evolves throughout entire geologic periods or eras tends to do so in discontinuous steps in which lengthy episodes of stagnation exceed those of active karst processes. For example, certain karst areas of the Rocky Mountains and Black Hills (western U.S.A.) have undergone at least 7 different stages over the past 350 my but were actively forming only about $20 \%$ of that time. Jewel and Wind Caves in South Dakota are good examples (Fig. 8). With mapped lengths of 218 and $196 \mathrm{~km}$, they are among the most complex caves in both pattern and diversity of geologic history. Each successive set of features was superposed on the previous ones, because each provided favorable sites for those that followed. Os-

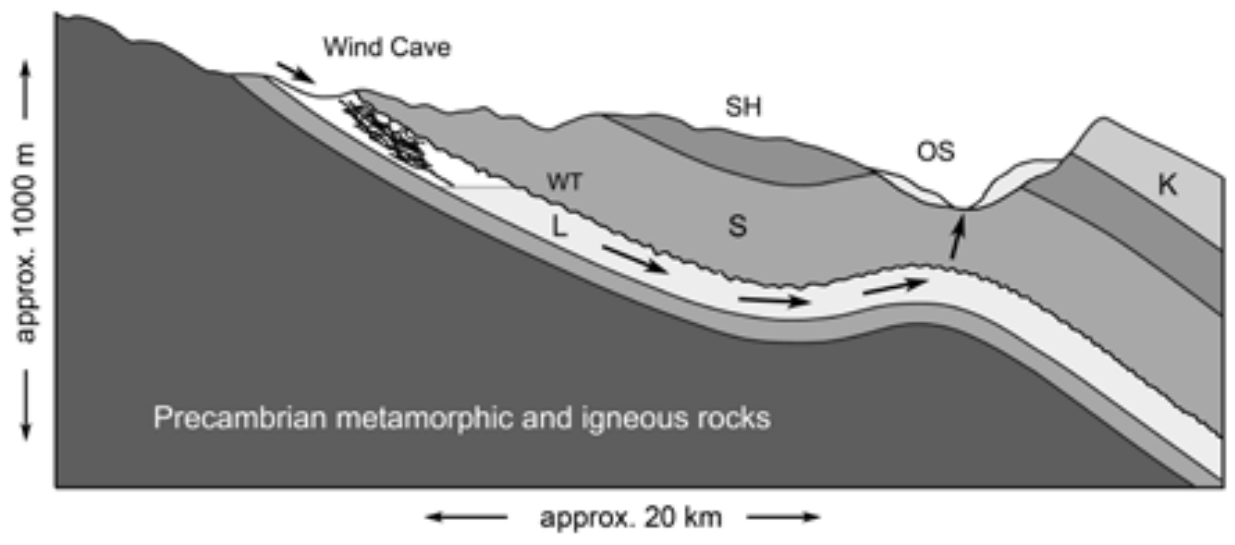

Fig. 8: Geologic setting of Wind Cave, South Dakota. L = Madison Limestone (early Carboniferous) underlain by thin Cambrian sandstone, $S=$ late Carboniferous sandstone, $S H=$ mainly shale, $K=$ Cretaceous sandstone, OS = Oligocene sediment (mainly siltstone, widely eroded). The upper surface of the Madison is irregular paleokarst. WT =water table in lowest passage of Wind Cave. The cave extends only a few meters below the water table. Arrows show dominant flow pattern of today. borne et al. (2006) describe a similarly complex history in the Jenolan Caves of Australia.

The major stages of karst development in the Black Hills are outlined below (Palmer \& Palmer, 1989, 1995):

1. Early Carboniferous carbonates of the Madison Formation were deposited on a low-gradient continental shelf. Interbedded sulfates were included in the middle and upper Madison.

2. Brecciation and early voids formed by dissolution and reduction of sulfates, plus production of sulfuric acid (Fig. 9). Sulfate rocks were almost completely removed.

3. A mid-Carboniferous karst formed throughout much of western North America (Sando, 1988). Surface features included fissures and dolines up to $30 \mathrm{~m}$ deep. Caves concentrated at 20-50 m below the surface along former sulfate zones and intersect earlier breccias and caves (Fig. 10). Comparison with modern caves suggests some freshwatersaltwater mixing dissolution.

4. The karst was buried by late Carboniferous detrital sediment, and most caves were completely filled. The sedimentary burial continued through the Cretaceous to a depth of 


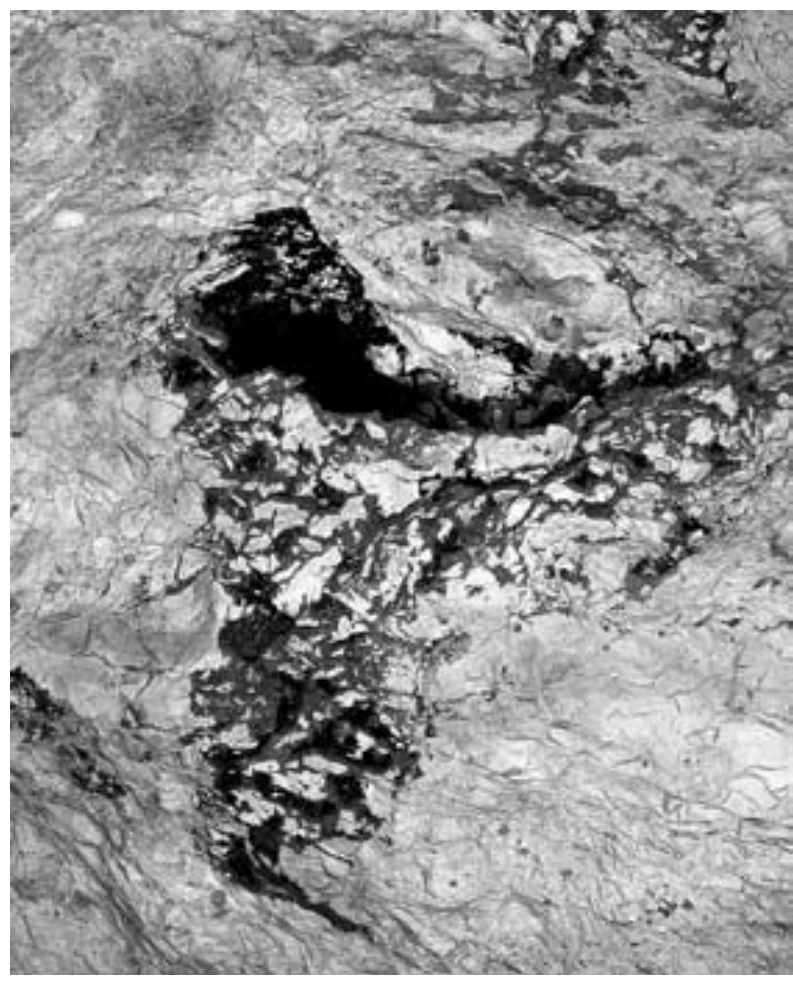

Fig. 9: Early solution voids and brecciation related to early Carboniferous sulfate-carbonate interactions in Jewel Cave, South Dakota. These are exposed by collapse of wall of a later cave. Height of photo is about $2 \mathrm{~m}$.

at least $2 \mathrm{~km}$. Buried caves and vugs, as well as voids in the Carboniferous sediment, were lined by white scalenohedral calcite about 1-2 cm thick (Fig. 11). Pre-burial

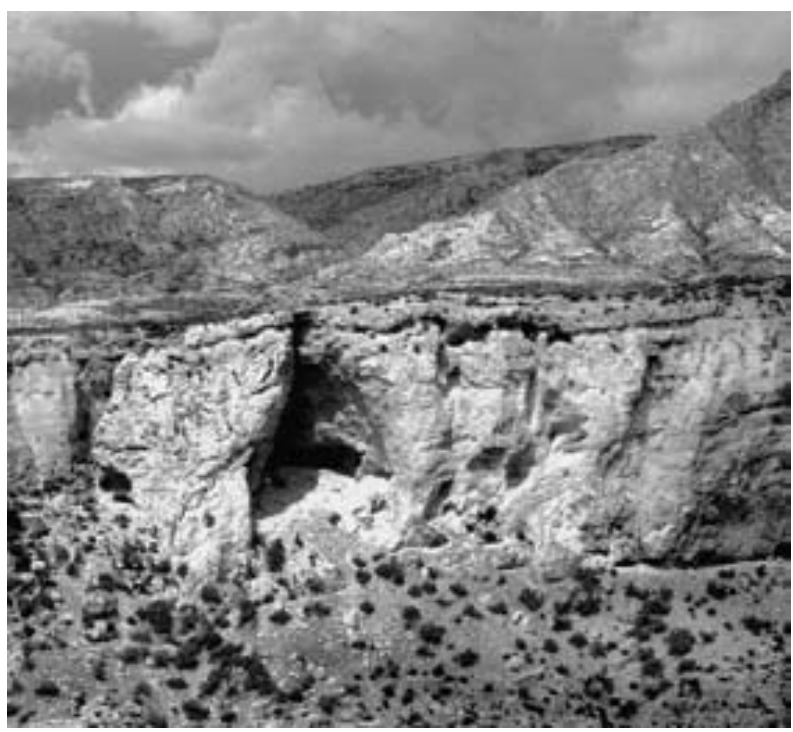

Fig. 10: Mid-Carboniferous paleokarst, Bighorn Mountains, Wyoming. Caves in cliff were once filled with late Carboniferous sediment, but much of it has been removed by weathering and stream erosion.
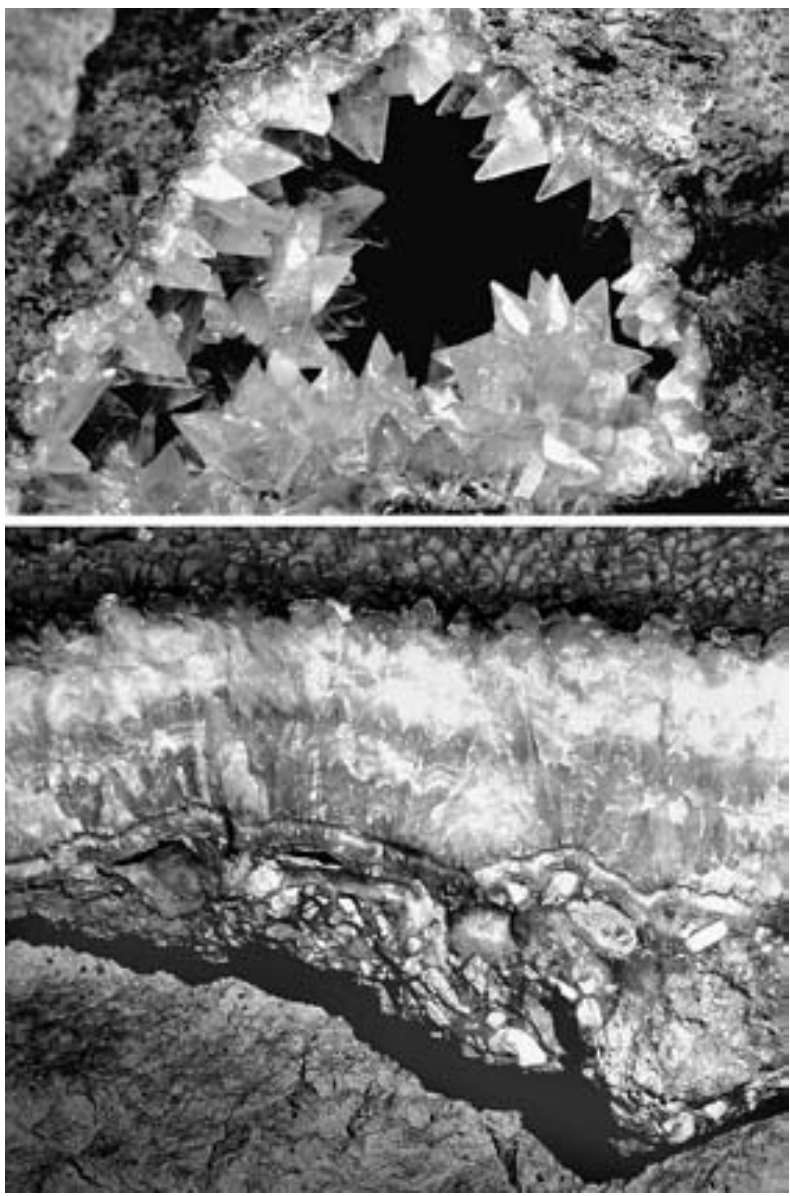

Fig. 11: Top: Scalenohedral calcite coating of Mesozoic age on walls of Carboniferous vug, Wind Cave (crystal length $~ 1.5$ $\mathrm{cm}$ ). Bottom: Rhombohedral calcite coating of late Tertiary age on weathered walls of an early Tertiary passage, Jewel Cave ( maximum thickness of calcite $=15 \mathrm{~cm}$ ).

voids can be recognized by this distinctive coating. Along faults, surfaces were coated by euhedral quartz up to a 5 mm thick.

6. The Black Hills and Rocky Mountains were uplifted by the Laramide orogeny (latest Cretaceous through Eocene; Fig. 8). The climate was more humid than today's, and the present topography above the caves was formed by the end of the Eocene. Enhanced groundwater flow enlarged earlier caves to their present form (Fig. 12). Their layout shows evidence for mixing between shallow and deep water (Palmer and Palmer, 1989), although Bakalowicz et al. (1997) suggest a purely thermal origin.

7. The caves drained and were exposed to subaerial weathering, which produced thick carbonate deposits in many passages.

8. Most of the Eocene landscape was buried by Oligocene sediments during a drying of the climate. Although much of this sediment has been removed by later 


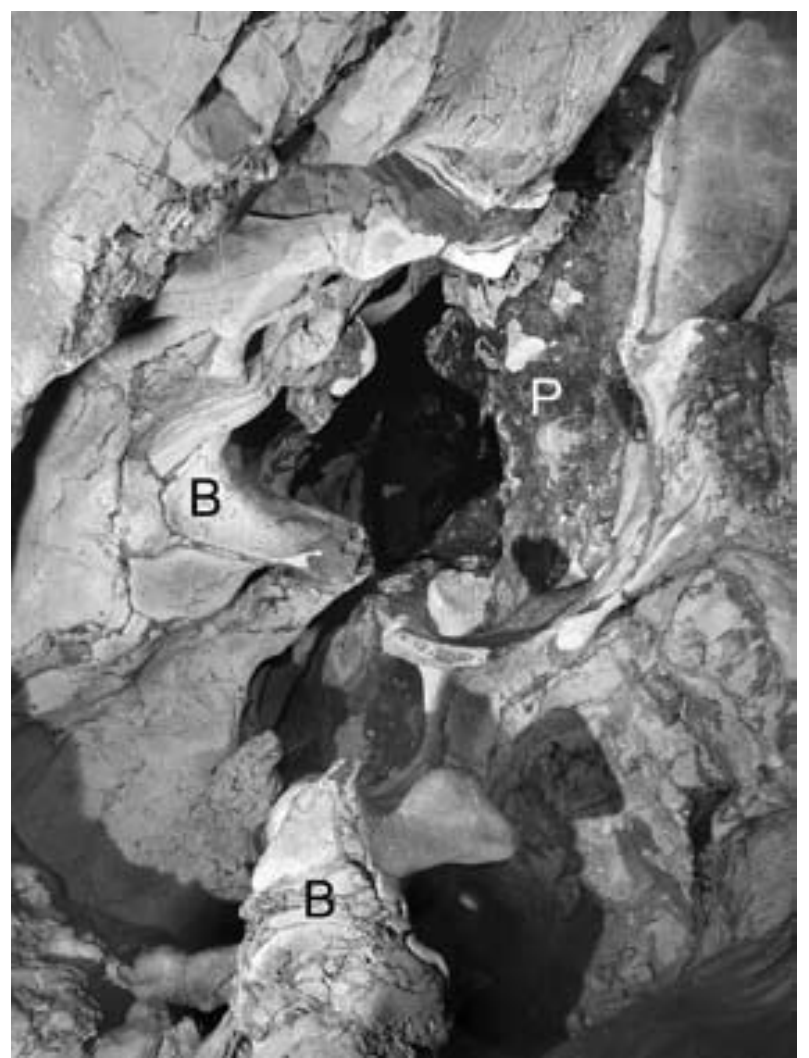

erosion, the Eocene landscape on the resistant PaleozoicMesozoic rocks has survived almost intact, as have the underlying caves, thanks to the present semi-arid climate.

9. Partial blockage of springs by Oligocene sediments caused a second phase of calcite coating (mainly rhombohedral) averaging $15 \mathrm{~cm}$ thick in Jewel Cave (Fig. 11) but thinner in Wind Cave. The earlier scalenohedral coating is still visible in pockets and vugs that were isolated from the cave development and exposed by later breakdown.

In this sequence there is little information about developmental rates. Instead, the karst history is portrayed as a series of discrete episodes, which span a wide range of processes, groundwater conditions, tectonic relationships, and levels of diagenetic maturity of the host strata. All effects have overlapped, and in some caves it is possible to stand in a single spot and distinguish every phase of their history.

Fig. 12: Typical cave passage of Eocene age in Wind Cave, showing remnants of earlier breccia $(B)$ and paleo-fill $(P)$. Height of photo is about $2 \mathrm{~m}$.

\section{CONCLUSIONS}

Karst processes operate at rates that vary considerably with time, and the magnitude of that variation is generally greater as the developmental time span increases. At every time scale, the developmental history of karst (at least in the examples described here) includes episodes of stagnation and of retrograde development when material is deposited instead of removed.

Modern measurements of the rates of karst processes can be extrapolated into the past, but this extrapolation becomes more suspect as the time span increases. Over the entire growth history of major cave systems (usually $10^{6}-10^{7}$ years), many disruptions in rate are caused by changes in climate, base level, and river patterns. At time scales of $10^{7}-10^{8}$ years, interpretation of evolutionary rates becomes difficult, and the history of karst is usually subdivided into discrete episodes, in the same manner as tectonic and sedimentary events.
As a karst feature develops toward maturity, it tends to undergo inherent changes in developmental rate. For example, a cave may decrease in enlargement rate as entrances open and enlarge, allowing greater rates of $\mathrm{CO}_{2}$ loss. Rates of karst development may increase with time as dolines develop and enlarge, owing to greater exposure of soluble rock and accumulation of high- $\mathrm{CO}_{2}$ soils in depressions.

It is impossible to interpret caves and karst without a solid understanding of their surrounding geology and physiography. But, despite uncertainties about their rates of development, karst features can provide more information about the surrounding landscape than vice versa. 


\section{REFERENCES}

Anthony, D.M. \& D.E. Granger, 2004: A Late Tertiary origin for multilevel caves along the western escarpment of the Cumberland Plateau, Tennessee and Kentucky, established by cosmogenic ${ }^{26} \mathrm{Al}$ and ${ }^{10} \mathrm{Be}$. - Journal of Cave and Karst Studies, 66, 2, 46-55.

Anthony, D.M. \& D.E. Granger, 2006: Five million years of Appalachian landscape evolution preserved in cave sediments. - In R.S. Harmon and C.M. Wicks (eds.): Perspectives on karst geomorphology, hydrology, and geochemistry - A tribute volume to Derek C. Ford and William B. White: Geological Society of America, Special Paper 404, 39-50.

Anthony, D.M. \& C.G. Groves, 1997: Preliminary investigations of seasonal changes in the geochemical evolution of the Logdson River, Mammoth Cave, Kentucky. - Proceedings of $6^{\text {th }}$ Science Conference, 15-23, Mammoth Cave, Kentucky.

Bakalowicz, M.J., D.C. Ford, T.E. Miller, A.N. Palmer \& M.V. Palmer, 1987: Thermal genesis of dissolution caves in the Black Hills, South Dakota. - Geological Society of America Bulletin, 99, 729-738.

Dumont, K.A., 1995: Karst hydrology and geomorphology of the Barrack Zourie Cave System, Schoharie County, New York. - M.S. thesis, Mississippi State University, p. 71, Mississippi State, Mississippi.

Gams, I., 1965: Types of accelerated corrosion. - In O. Štelcl (ed.): Problems of the speleological research. - International Congress of Speleology, 133-139, Brno, Czech.

Granger, D.E., D. Fabel \& A.N. Palmer, 2001: PliocenePleistocene incision of the Green River, Kentucky, determined from radioactive decay of cosmogenic ${ }^{26} \mathrm{Al}$ and ${ }^{10} \mathrm{Be}$ in Mammoth Cave sediments. - Geological Society of America Bulletin, 113, 7, 825-836.

Granger, D.E., J.W. Kirchner, \& R.C. Finkel, 1997: Quaternary downcutting rate of the New River, Virginia, measured from differential decay of cosmogenic ${ }^{26} \mathrm{Al}$ and ${ }^{10} \mathrm{Be}$ in cave-deposited alluvium. - Geology, 25, 107-110.

Groves, C. \& J. Meiman, 2005: Weathering, geomorphic work, and karst landscape evolution in the Cave City groundwater basin, Mammoth Cave, Kentucky. - Geomorphology, 67, 115-126.

Hess, J.W., 1974: Hydrochemical investigations of the central Kentucky karst aquifer system. - Ph.D. dissertation, Pennsylvania State University, p. 218, University Park, Pennsylvania.
Hess, J.W. \& W.B. White, 1993: Groundwater geochemistry of the carbonate aquifer, south-central Kentucky, U.S.A. - Applied Geochemistry, 8, 189-204.

Lauritzen, S.-E. \& J.E. Mylroie, 2000: Results of a speleothem U/Th dating reconnaissance from the Helderberg Plateau, New York. - Journal of Cave and Karst Studies, 62, 1, 20-26, Huntsville, Alabama.

Meiman, J. \& C. Groves, 1997: Magnitude/frequency analysis of cave passage development in the Central Kentucky Karst. - Proceedings of 6th Science Conference, 11-13, Mammoth Cave National Park, Kentucky.

Mylroie, J.E. \& J.R. Mylroie, 2004: Glaciated karst: How the Helderberg Plateau revised the geologic perception. - Northeastern Geology and Environmental Sciences, 26, 1-2, 82-92, Troy, New York.

Osborne, R.A.L., H. Zwingmann, R.E. Pogson \& D.M. Colchester, 2006: Carboniferous clay deposits from Jenolan Caves, New South Wales: Implications for timing of speleogenesis and regional geology. - Australian Journal of Earth Science, 53, 377-406.

Palmer, A.N., 1981: A geological guide to Mammoth Cave National Park. - Zephyrus Press, p. 210, Teaneck, New Jersey.

Palmer, A.N., 1991: Origin and morphology of limestone caves. - Geological Society of America Bulletin, 103, $1-21$.

Palmer, A.N.,1995: Geochemical models for the origin of macroscopic solution porosity in carbonate rocks. - In Budd, D.A., P.M. Harris, \& A. Saller (eds.): Unconformities in carbonate strata: Their recognition and the significance of associated porosity. - American Association of Petroleum Geologists, Memoir 63, 77-101.

Palmer, A.N., 1996: Rates of limestone dissolution and calcite precipitation in cave streams of east-central New York State. - Abstracts of Northeastern Section meeting, Geological Society of America, 28, 3, 89.

Palmer, A.N. \& M.V. Palmer, 1989: Geologic history of the Black Hills caves, South Dakota. - National Speleological Society Bulletin, 51, 2, 72-99.

Palmer, A.N. \& M.V. Palmer, 1995: The Kaskaskia paleokarst of the Northern Rocky Mountains and Black Hills, northwestern U.S.A. - Carbonates and Evaporites, 10, 2, 148-160, Troy, New York.

Palmer, M.V. \& A.N. Palmer, 1975: Landform development in the Mitchell Plain of southern Indiana: Origin of a partially karsted plain. - Zeitschrift für Geomorphologie, 19, 1-39. 
Plummer, L.N., T.M.L. Wigley, T.M.L. \& D.L. Parkhurst, 1978: The kinetics of calcite dissolution in $\mathrm{CO}_{2}$-water systems at $5^{\circ}$ to $60^{\circ} \mathrm{C}$ and 0.0 to $1.0 \mathrm{~atm} \mathrm{CO}_{2}$. - American Journal of Science, 278, 179-216.

Quinlan, J.F., R.O. Ewers, J.A. Ray, R.L. Powell \& N.C. Krothe, 1983: Ground-water hydrology and geomorphology of the Mammoth Cave Region, Kentucky, and of the Mitchell Plain, Indiana. - Indiana Geological Survey, Field trips in Midwestern geology, 2, 1-85, Bloomington, Indiana.
Ray, J.A., 1996: Fluvial features of the karst-plain erosion surface in the Mammoth Cave region. - Proceedings of 5th Science Conference, 137-156, Mammoth Cave, Kentucky.

Sando, W.J., 1988: Madison Limestone (Mississippian) paleokarst: A geologic synthesis. - In N.P. James and P.W. Choquette (eds.): Paleokarst: Springer-Verlag, 256-277, New York. 